\title{
Pes planovalgus
}

\section{Pes planovalgus}

\author{
Serkan Erkuş, Önder Kalenderer
}

Sağlık Bilimleri Üniversitesi Tepecik Eğitim ve Araştırma Hastanesi, Ortopedi ve Travmatoloji Kliniği, İstanbul

Pes planus, çocukluk çağında aileleri hekime yönlendiren en önemli nedenlerden biridir. İlk üç yaşta, ayak altı yumuşak doku yapılarından dolayı düztabanlık tanısı konulamaz. Çoğu pes planus esnektir, sorun oluşturmaz ve tedavi gerektirmez. Nadiren, pes planusun altında daha ciddi sorunlar yatabilir. Aşil kısalığı, ayak bileği, subtalar eklem hareket açıklığı sorunları ve ağrısı olan olgularda dikkatli olunmalı, ayrıntılı araştırmaya gidilmelidir.

Anahtar sözcükler: pes planus; pes planovalgus; düztabanlık; çocuk
Pes planus in childhood is one of the most important reasons leading families to a physician. In the first three years, it can not be diagnosed because of the soft tissue structures under the feet. Most pes planus is flexible, and do not cause problems and treatment is not necessary. Rarely, more serious problems can arise due to pes planus. Careful attention should be paid and detailed investigations should be made in cases of Achilles shortness, problems related to ankle and sub-articular motion range, and pain.

Key words: pes planus; pes planovalgus; flatfoot; child es planovalgus deformitesi, çocukluk çağında en sık rastlanılan ve sıklıkla herhangi bir sorun oluşturmayan bir ayak sorunudur. Nasıl hepimizin yüzü birbirinden farlı ise ayak yapılarımızın da birbirinden farklı olması o kadar doğaldır. Hepimizin ayak izleri birbirinden farklıdır.

Pes planus, ayağın mediyal longitudinal arkının yüklenme esnasında çökmesi olarak basitçe tanımlanabilir (Şekil 1); arkın çökmesine ayak önü, ortası ya da arkasının deformiteleri de eklenirse pes planovalgus olarak adlandırılır. ${ }^{[1]}$ Arkın çökmesine, ayağın pronasyonu (Şekil 2), topuğun valgusu (Şekil 3) ve \%25 olguda Aşil kontraktürü (kısalığı) (Şekil 4) eşlik edebilir. Yere basmadan ayakta mediyal longitudinal ark olsa bile, yüklenmeyle (yere basma esnasında) bağ gevşekliği nedeniyle arkta çökme oluşabilir.

Çocuklarda tam sıklığı bilinmemekle birlikte, erişkinlerde \%20-25 oranında görüldüğü bildirilmektedir.

Pes planus veya planovalgus deformitesini kavrayabilmek için ayak anatomisinin iyi bilinmesi gerekir. Bölümün ayrıntılarına girmeden önce gerekli anatomik bilgilere kısaca değinilecektir.
Yedi tarsal kemik (talus, kalkaneus, naviküler, küboid, küneiformlar), beş metatars ve 14 falanks kemiği, ayağın kemiksel yapısını oluşturur. Bu kemiklerin kendi içindeki dizlimi ve bunlara yapışan kas ve bağların fonksiyonları, pes planusta etkili olur.

Pes planovalgusta önemli olan ayak ve bacak kaslarından kısaca söz edilecektir. M.tibialis anterior, tibianın dış yüzünden başlar, mediyal küneiform ve 1. metatarsın bazisi dorsaline yapışır. Ayağın en güçlü ekstansörüdür; supinasyon ve adduksiyona yardımcıdır; ayrıca ayak kubbesini korur. Triseps surae; M.gastrocnemius ve M.soleus kaslarından oluşur ve Aşil'e yapışarak sonlanır; ayağın en kuwvetli fleksör kasıdır. M.tibialis posterior, tibia ve fibula gövdesinin üst arka kısmından başlar ve naviküler ve etraf kemiklerine yelpaze şeklinde yapışarak sonlanır; ayağın mediyal longitudinal arkını korur ve en güçlü invertörüdür. M.peroneus longus, fibula başından başlar; mediyal küneiform ve 1. metatarsın bazisi plantarine yapışır; temel görevi pronasyondur, ayrıca fleksiyon ve abduksiyona yardımcıdır; ayak kubbesini koruyan kaslardandır. M.peroneus brevis, fibula dış $2 / 3$ alt yüzünden başlar ve 5 . metatars bazisi plantarinde sonlanır; ayağa pronasyon ve fleksiyon yaptırır.

- Iletişim adresi: Dr. Serkan Erkuş, İzmir Tepecik Eğitim ve Araştırma Hastanesi, Güney Mah. Gaziler Cad. No: 468 Konak, İzmir Tel: 0553 - 3253684 e-posta: s.erkus@ymail.com

- Geliș tarihi: 17 Kasım $2017 \quad$ Kabul tarihi: 17 Kasım 2017 


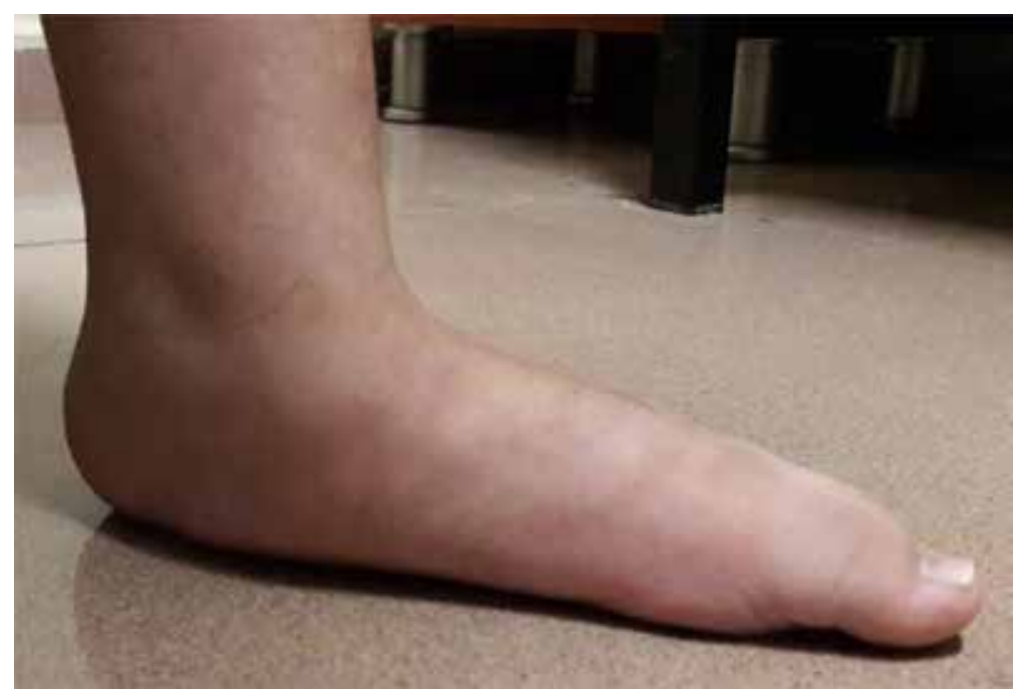

Şekil 1. Ayağın mediyal longitudinal arkının yüklenme esnasında çökmesi.

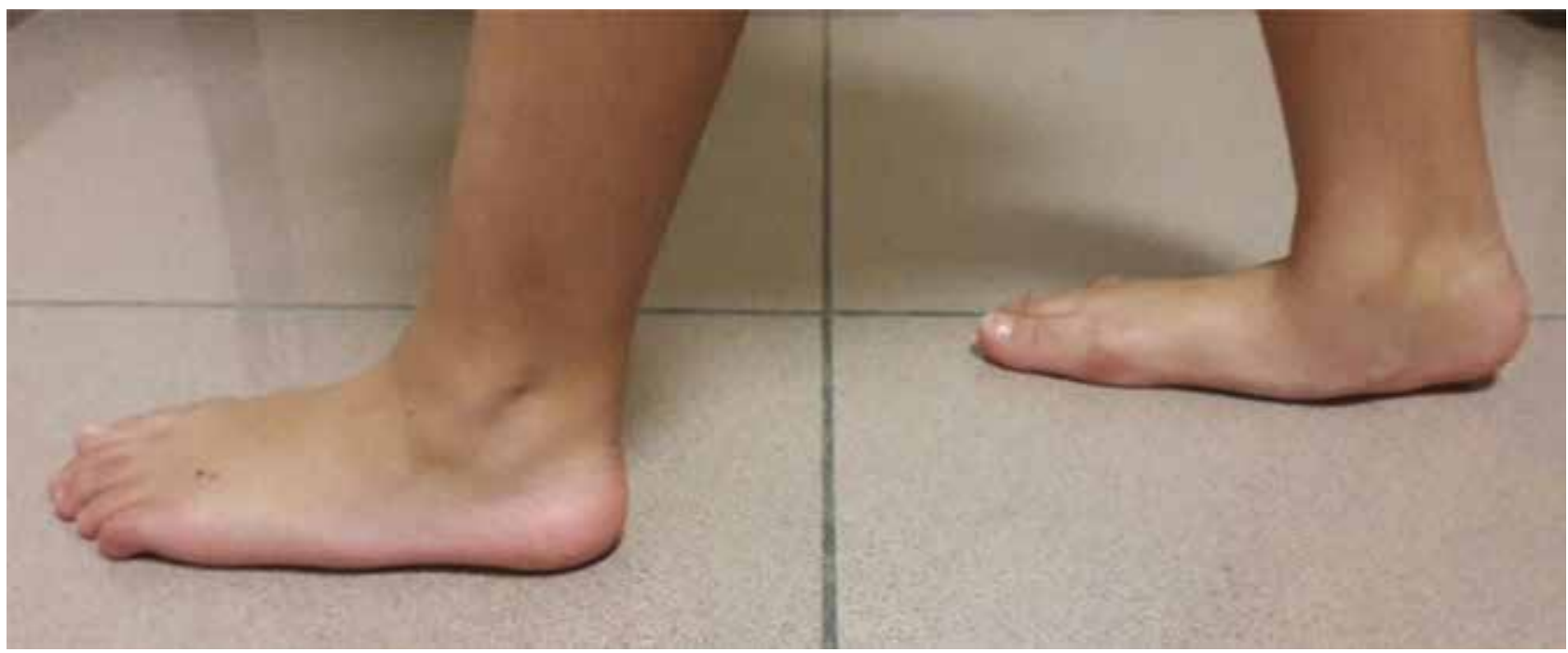

Şekil 2. Pes planusa eşlik eden ayak pronasyonu.

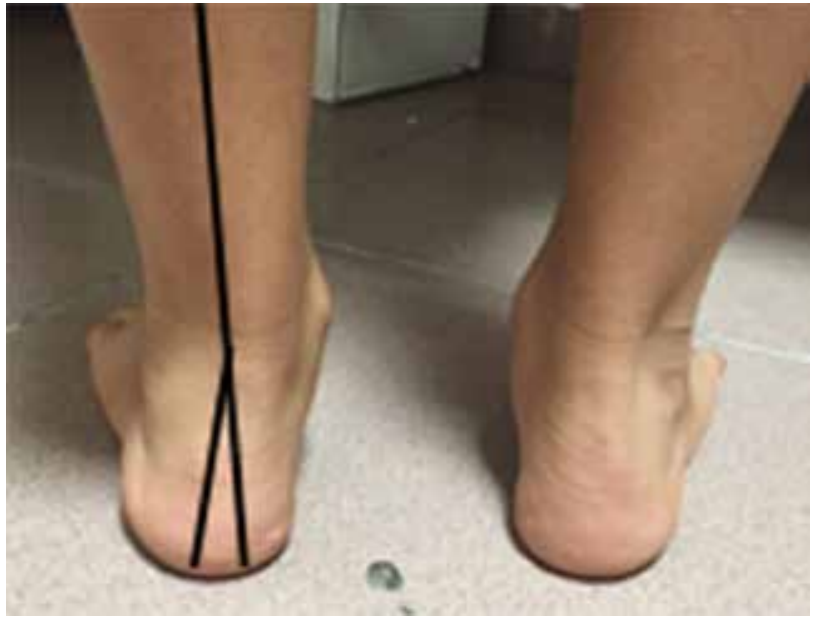

Şekil 3. Topuk valgusu.

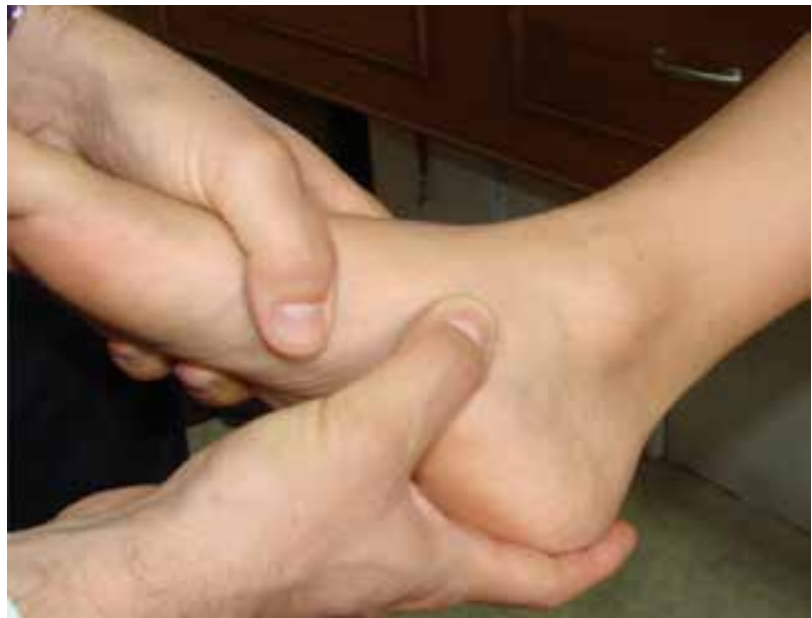

Şekil 4. Aşil kısalığı. 
Spring (plantar kalkaneo-naviküler) bağ, mediyal longitudinal arkı destekleyen en önemli yapıdır. Derin transvers bağlar ise transvers arkı destekler.

Ayak ve ayak bileği hareketlerinde, üç önemli eklem (tibiotalar, subtalar ve midtarsal) farklı görevler yapar. Tibiotalar eklem ile plantar fleksiyon ve dorsi fleksiyon hareketleri, subtalar eklem ile eversiyon ve inversiyon, midtarsal eklemler ile de supinasyon ve pronasyon hareketleri yapılır. Normalde, ayak bileği ekleminde dorsifleksiyon $20-30^{\circ}$, plantar fleksiyon $40-50^{\circ}$, supinasyon $35^{\circ}$, pronasyon $15^{\circ}$ ve subtalar eklemden inversiyon $20^{\circ}$, eversiyon $10^{\circ}$ 'dir.

Ayak, ark sistemlerinden oluşmuştur ve bu sistem "taş köprü" sistemine benzer. Ark mekanizmasında, aynı taş köprülerde olduğu gibi "key stone" denilen kilit taşı görevi yapan kemikler, kemikleri birbirine bağlayan "staples" denilen ara bağlantılar (bağlar), köprüleri ayakta tutan "tie beam" denilen kiriş yapıları (kas ve tendonlar) ve "suspension bridge" denilen askı yapıları (kaslar) vardır (Şekil 1-4). Tüm bu sistemin, yani ayakta ark mekanizmasının dengeli ve etkili çalışabilmesi için, ayakta üç adet temel ark sistemi vardır:

1. Mediyal longitudinal ark: Bu ark, pes planus ve planovalgusta tamamen çökmüştür. Bu arkı destekleyen kilit taşı talustur (Şekil 5). Sustentakulum tali talusu kaldırır, navikula talus başında, mediyal

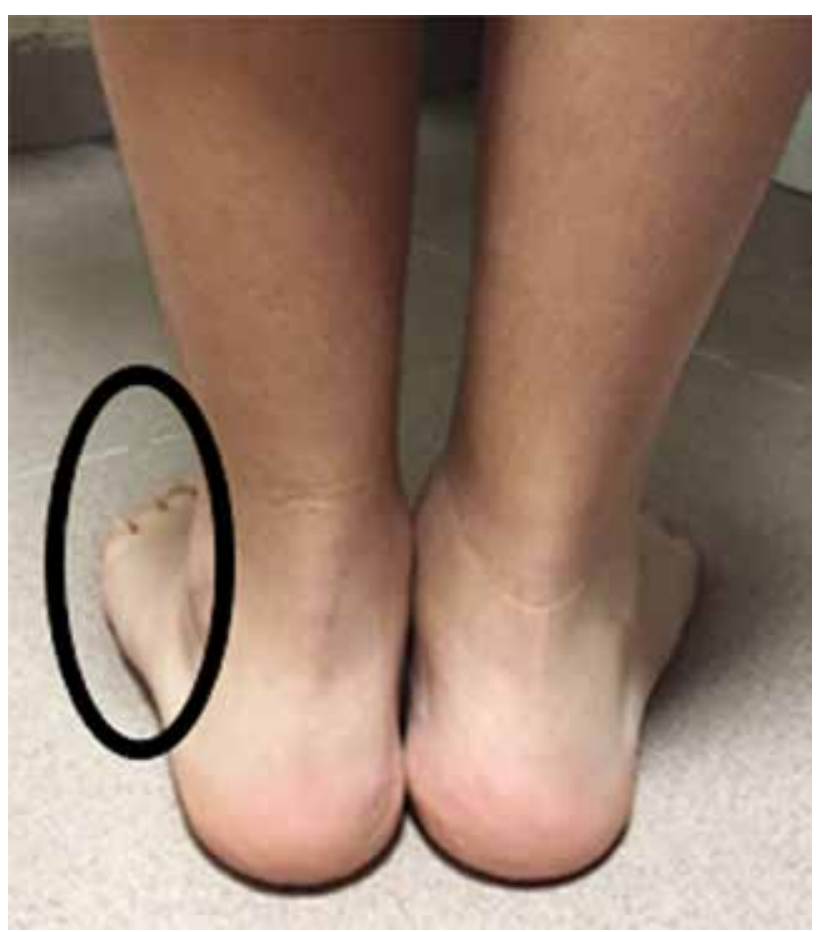

Şekil 5. Arkadan bakıldığında pes planusta ikiden fazla parmak görülür ("too many toes sign”). küneiformda navikula çevresinde kayar. Kemikleri bir arada tutan inferior ara bağlantılar plantar bağlardır. Bunlardan da en önemlisi spring ligament'tir. Tibialis posterior tendonu da bu yapıya destek olmaktadır. Yüklenmenin olmadığı durumlarda plantar bağlar gevşek durumdadır. Ayağın yere temasıyla (ayak arkında kompresyonla) plantar bağlar gerilir. Bu bağlar ne kadar iyi görev yaparsa mediyal arkta çökme de o kadar az olur. Buraya destek olan kiriş yapıları ise plantar aponevroz, FHL, FDL, FHB ve FDB tendonlarıdır. Tibialis anterior ve posterior kasları da mediyal longitudinal arkın çökmesine engel olan dinamik askı yapılarıdır. Bu kaslar ne kadar aktif ve güçlü olursa arkın çökmesi o kadar zor olur. ${ }^{[2,3]}$

2. Lateral longitudinal ark: Bu arkı destekleyen ve kilit taşı görevini yapan kemik küboiddir. Kemikleri bir arada tutan inferior yapılar; plantar bağlar ve kısa kasların başlangıç kısımlarıdır. Gergi bandı şeklinde görev yapan yapılar; plantar aponeuroz, abduktor dijiti minimi, FDL ve FDB tendonlarıdır. Peroneus longus ve brevis kasları da dinamik askı yapılarıdır.

3. Transvers ark: Anahtar kemikler küneiformlardır. Taşları yerinde tutan inferior yapı; derin transvers bağlar ve kısa kasların başlangıçlarıdır. Gergi bandı şeklinde yerinde tutan yapı; perenous longus tendonudur. Bu tendon, aynı zamanda dinamik askı görevi de yapmaktadır.

\section{Patolojik Anatomi}

Pes planovalgusta primer ve sekonder değişiklikler ortaya çıkar.

\section{Primer değişiklikler}

- Ayak önü; abduksiyonda ve ayağın arkasına göre supinasyondadır.

- Talus başı; anterior, inferior ve mediyale doğru deplasedir.

- Kalkaneus; eversiyon, valgus ve dorsifleksiyondadır.

- Navikula; talus başı üzerinde dorsolaterale sublukse durumdadır.

- Mediyal longitudinal ark; çökmüş ve lateral arka oranla daha uzundur.

\section{Sekonder değişiklikler}

- Navikula, küneiform ve küboid kemiklerin dorsolateral apekslerinde kamalaşma vardır.

- Plantar, deltoid ve spring bağlar; uzar, esner ve zayıflar.

- Tibialis anterior/posterior tendonları ve plantar kaslar; uzar, esner ve zayıflar.

- Aşil tendonu ve peroneal tendonlar kısalır.

- Mediyal kemik çıkıntıları hizasında ciltte kalınlaşma ve nasırlaşma oluşur. 


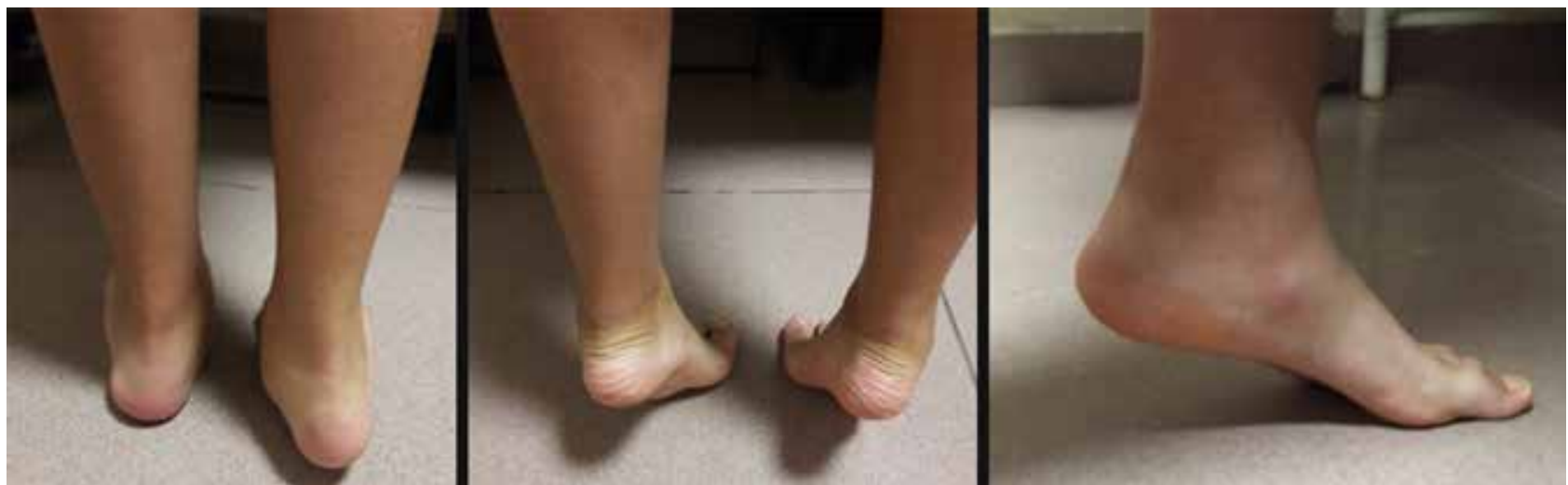

Şekil 6. Parmak ucu yürümede topuktaki valgus deformitesi düzeliyorsa deformite esnektir.

\section{FiZiK MUAYENE}

Çocuğun muayenesi inspeksiyonla başlar. Çocuğun ayakkabılı ve ayakkabısız yürüyüşü mutlaka incelenmelidir. Çocuğun ayağında nasır, şekil bozukluğu veya deformiteler gözlenmelidir. Çocuk ayağını yere bastığı zaman mediyal longitudinal arkın çöktüğü görülür. Topuklar mutlaka incelenmelidir ve valgus deformitesi olup olmadığı kayıt altına alınmalıdır. Normalde, topuklara arkadan bakarken sadece beşinci parmaklar görülür. Daha fazla parmağın görülmesi ("too many toes sign”) düztabanlık lehinedir (Şekil 5); mediyal longitudinal arkın çöktüğünün ve ayağın pronasyona gittiğinin klinik göstergesidir. Çocuğun normal yürüyüşü dışında, parmak uçlarında ve topukları üzerinde yürüyüşü de incelenmelidir. Bunlar, deformitenin esnek veya sert olup olmadığı konusunda ayırıcı tanıda çok önemlidir. Parmak ucu yürümede topukta var olan valgus deformitesi düzeliyorsa; bu, deformitenin esnek olduğunun göstergesidir (Şekil 6).

Palpasyonda, hastanın ayağında varsa ağrılı noktalar ve tüm kemik çıkıntıları (özellikle aksesuvar naviküler kemik düşünülen durumlarda) değerlendirilmelidir. Ayak bileği ve subtalar eklem hareket açıklıkları mutlaka iki taraflı olarak ölçülmelidir (Şekil 7).

\section{Aşil Kısalığı (Ekin Kontraktürü)}

Aşil kısalı̆̆ının (ekin kontraktürü) pes planusu \%25 olguda eşlik edebileceğini başlarda belirtmiştik. Subtalar eklem sabitlenerek aşil kısalığının olup olmadığı mutlaka incelenmelidir. Subtalar eklem sabitlenmezse aşil kısalığı gözden kaçırılabilir. Diz hem fleksiyonda hem de ekstansiyonda aşil kısalığı bakılmalıdır. Tibialis anterior, tibialis posterior, peroneus longus ve aşil kas güçleri mutlaka değerlendirilmeli ve karşı ayak ile karşılaştırılmalıdır.

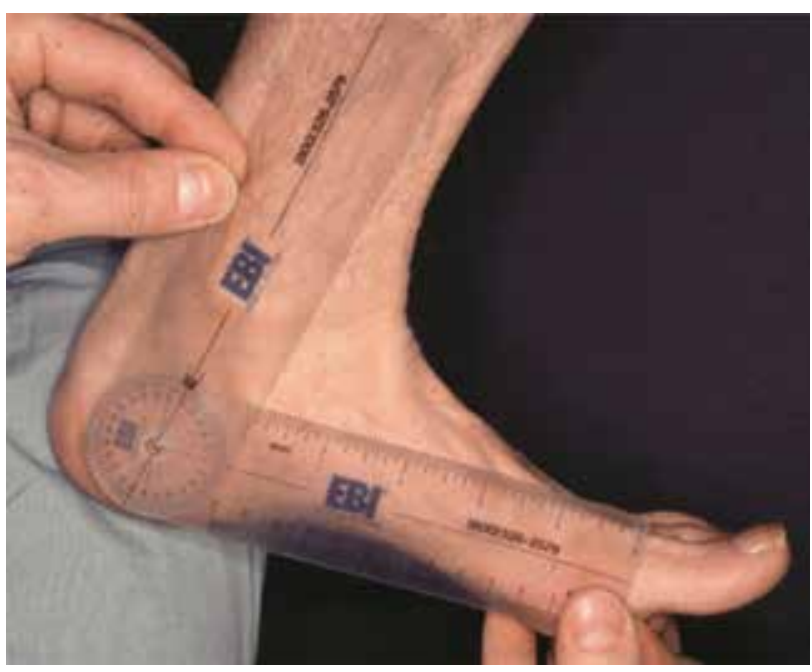

Şekil 7. Ayak bileği eklem hareket açıklığının gonyometre ile ölçümü.

\section{Jack Testi}

Birinci parmak dorsifleksiyon testidir. Nötral pozisyonda duran ayakta birinci parmağın dorsifleksiyona zorlanması ile mediyal longitudinal ark oluşuyorsa test pozitiftir (Şekil 8). Bu, pes planus deformitesinin esnek olduğunun ve egzersiz ile ayak şeklinin sağlanabileceğinin en önemli göstergelerinden biridir. ${ }^{[4]}$

Bazen, diz ve kalça deformiteleri ikincil deformite pes planus ile karşımıza çıkabilir. "O" bacak veya " $X$ " bacak mutlaka araştırılmalıdır. Ayrıca, tibia ve femurda eversiyon kusurları çok önemlidir. ${ }^{[5]}$ Tibial internal veya eksternal rotasyon deformiteleri (Şekil 9) veya artmış ya da azalmış femoral anteversiyon ölçümleri mutlaka yapılmalıdır.

Hasta çocuklarda, ayaklar kadar giydiği ayakkabıların da muayene edilmesi gerekir. Aileler sıklıkla, ayakkabıların ve özellikle topuk bölgelerin iç kısımlarının 


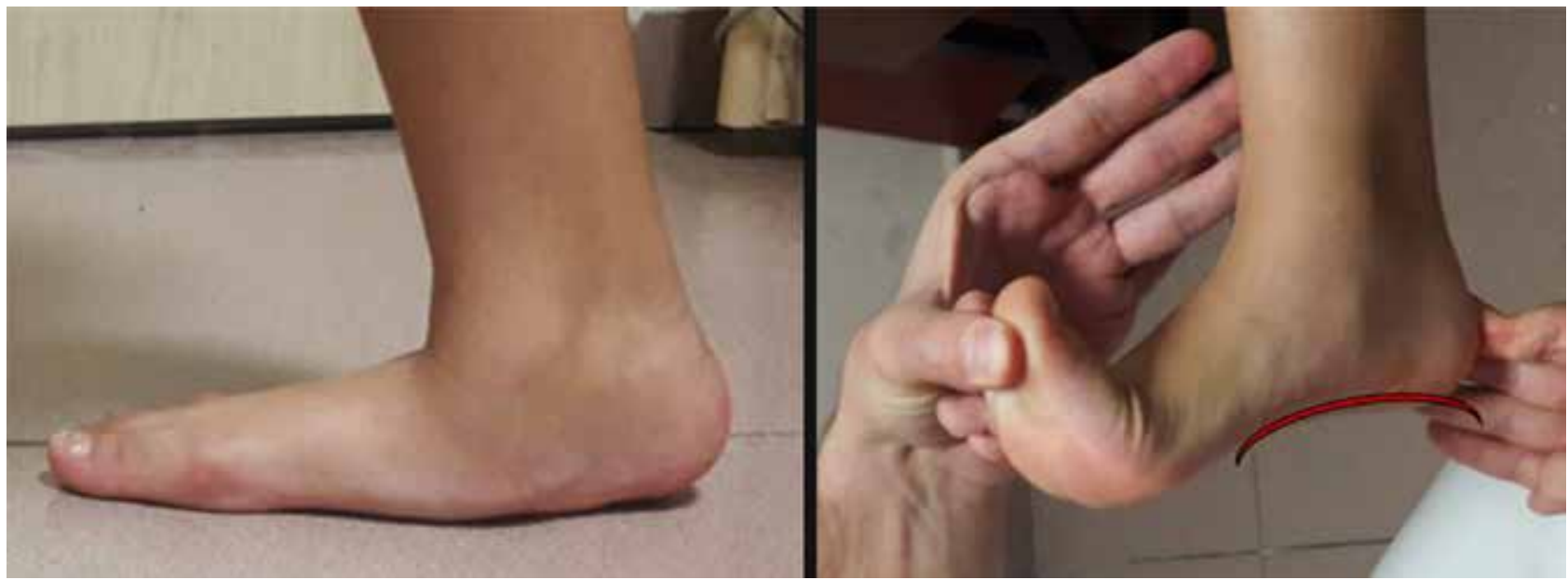

Şekil 8. Jack testi. Nötral pozisyonda duran ayakta birinci parmağın dorsifleksiyona zorlanması ile mediyal longitudinal ark oluşuyorsa test pozitiftir.

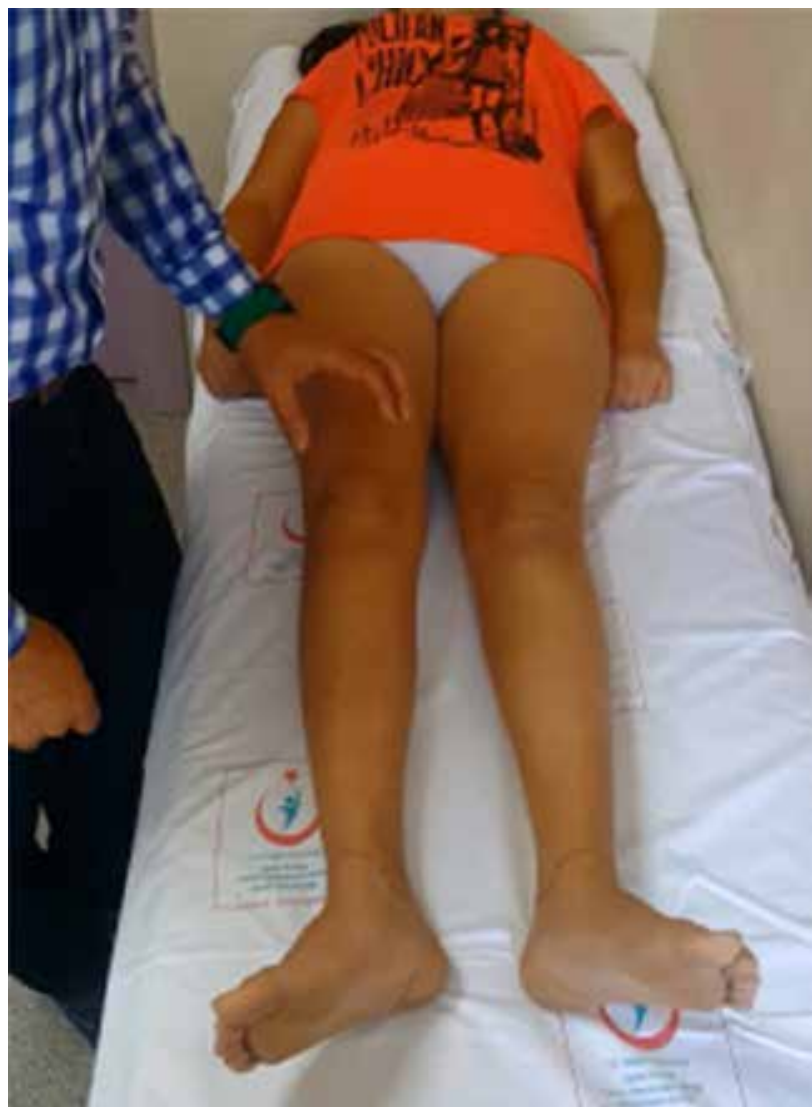

Şekil 9. Eksternal tibial torsiyon yanılgılara neden olabilir. Torsiyon veya versiyon kusurları mutlaka araştırılmalıdır.

kısa sürede bozulduğundan; ayakkabının çocuğun ayağının şeklini aldığından şikâyetçi olurlar. Bu yüzden, ayakkabıların muayenesi çok önemlidir ve asla unutulmamalıdır.

\section{Pedobarografik İnceleme}

Çocuk hastalar, laboratuvar koşullarında pedobarogram üzerinde yürütülür; ayak tabanının yere temas ettiği noktalardaki basınçları ölçülür. Daha çok akademik çalışmalar amacıyla kullanılır, rutin pratiği çok yoktur. Ameliyat öncesi planlama ve ameliyat sonrası nicel değerlendirme amacıyla önerilebilir. Özel tabanlık ve ortez uygulamalarında yararlı olabilir. Cam zemin üzerinde yürütülerek de aynı inceleme yapılabilir; ya da ayak baskısı yapılabilir. Normal ayakta asıl basınç noktaları metatars başları ve lateral longitudinal ark iken, pes planusta ayak mediyal longitudinal arkında da basınç izleri görülür.

\section{RADYOLOJiK DEĞERLENDIRME}

Standart basarak (yüklenmede) ön-arka, yan ve oblik grafiler çoğu olguda yeterlidir. Nadiren ultrasonografi (US), bilgisayarlı tomografi (BT) veya manyetik rezonans (MR) görüntüleme ayırıcı tanı amacıyla gerekli olabilir.

Ayak ön-arka grafilerinde aşağıdaki ölçümler yapılmalıdır (Şekil 10):

- Anterior talo-kalkaneal açı (Kite açısı: $15^{\circ}-30^{\circ}$ )

- Talus-1. metatars açısı (Simmon açısı: $-5^{\circ}-5^{\circ}$ )

- Talo-naviküler örtünme açısı

Erkek: $1,8^{\circ}-19,3^{\circ}$

Kız: $6,7^{\circ}-21,7^{\circ}$

- Kalkaneus-5. metatars açısı

- Intermetatarsal açı $\left(<9^{\circ}\right)$

- Halluks valgus açısı $\left(<15^{\circ}\right)$

- Halluks valgus interfalangeal açı $\left(<10^{\circ}\right)$

- Aksesuvar navikula

- CYMA hattı 


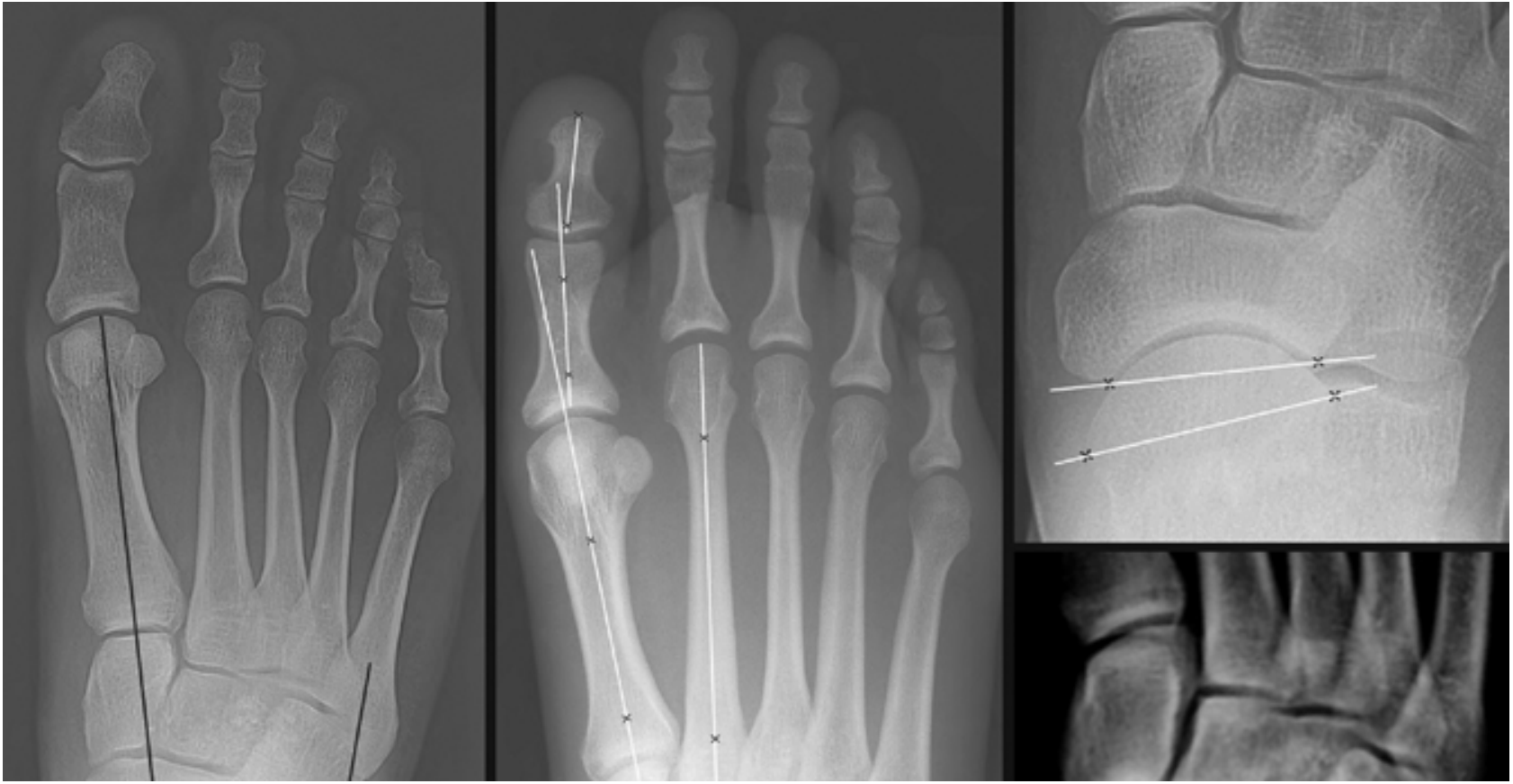

Şekil 10. Pes planusta, ön-arka grafide ölçülmesi gereken açılar.

Ayak yan grafilerinde şu ölçümler yapılmalıdır (Şekil 11):

- Lateral talo-kalkaneal açı $\left(35^{\circ}-50^{\circ}\right)$

- Kalkaneal pitch açısı $\left(15^{\circ}-30^{\circ}\right)$

- Böhler açısı $\left(22^{\circ}-48^{\circ}\right)$

- Gissane açısı $\left(120^{\circ}-140^{\circ}\right)$

- Talus-1. metatars açısı (Meary açısı: $-4^{\circ}-4^{\circ}$ )

- 5. metatars bazis yüksekliği $(2,3-3,8 \mathrm{~cm})$

- Hibbs açısı $\left(130^{\circ}-160^{\circ}\right)$

- Djian Annoier açısı $\left(115^{\circ}-135^{\circ}\right)$

- CYMA hattı

\section{Ultrasonografik İnceleme}

Tendon anatomisini, bağ rüptürlerini, tarsal koalisyonu değerlendirmek ve enjeksiyona rehberlik etmek amacıyla kullanılabilir.

\section{Bilgisayarlı Tomografi}

Travma, tarsal koalisyon ve tümöral lezyonlar, özellikle osteoid osteoma ayırıcı tanısı için yararlı bir inceleme yöntemidir (Şekil 12).

\section{Manyetik Rezonans}

Akut bağ hasarı, tarsal koalisyon, spring bağ hasarı, osteokondral lezyonları ve anterior, lateral ve posterior ayak bileği çevresi sıkışmalarını göstermek için kullanılabilir (Şekil 13).

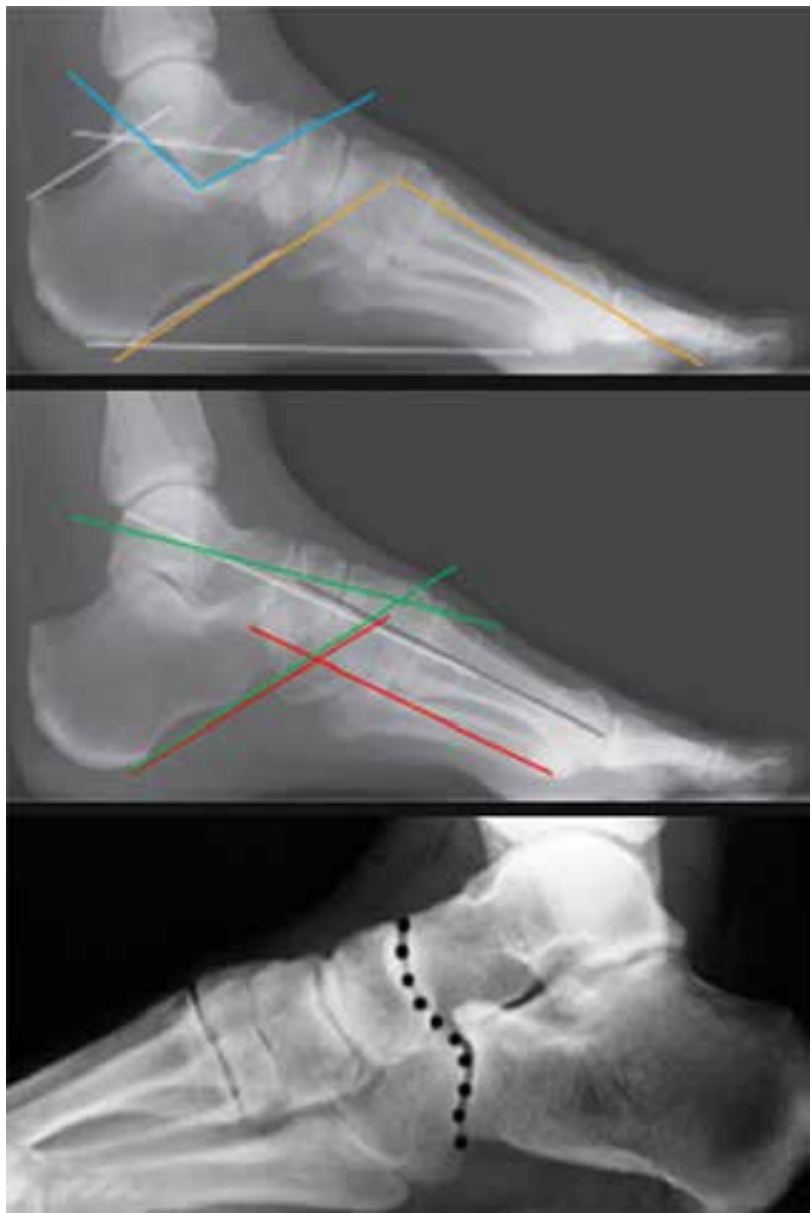

Şekil 11. Pes planusta, ön-arka grafide ölçülmesi gereken açılar. 


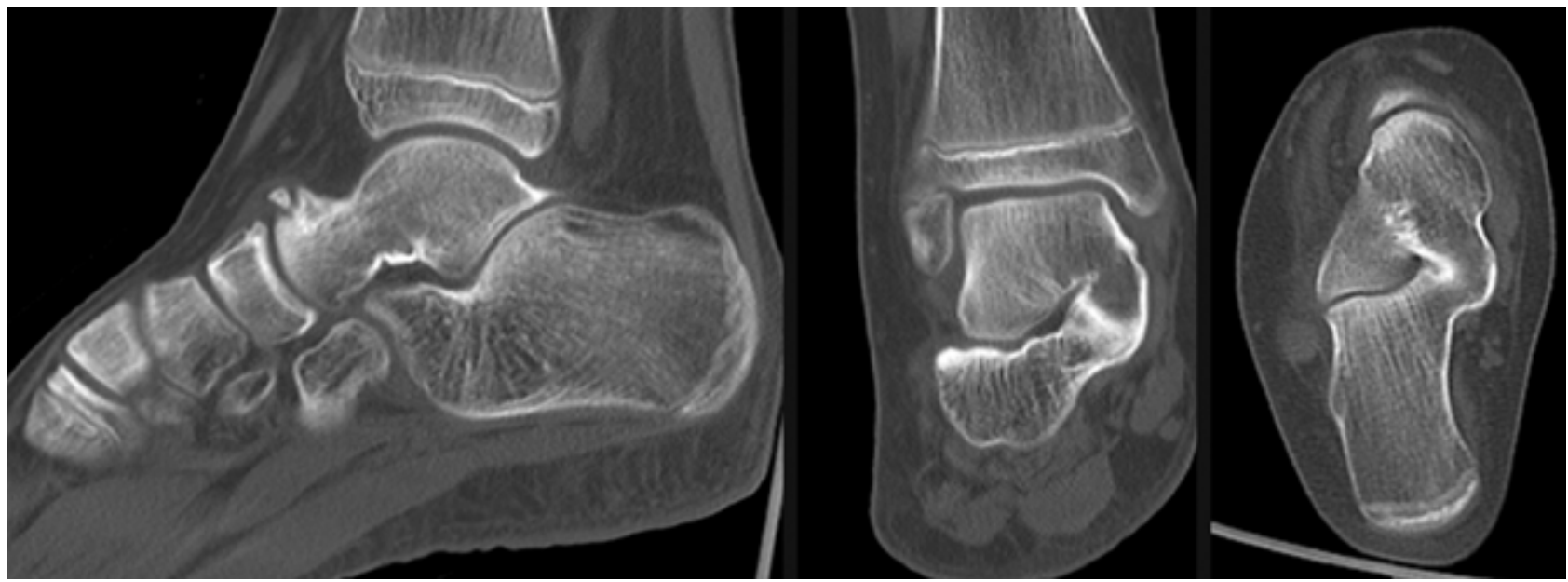

Şekil 12. Bilgisayarlı tomografi tarsal koalisyonda önemli bir tanı aracıdır.

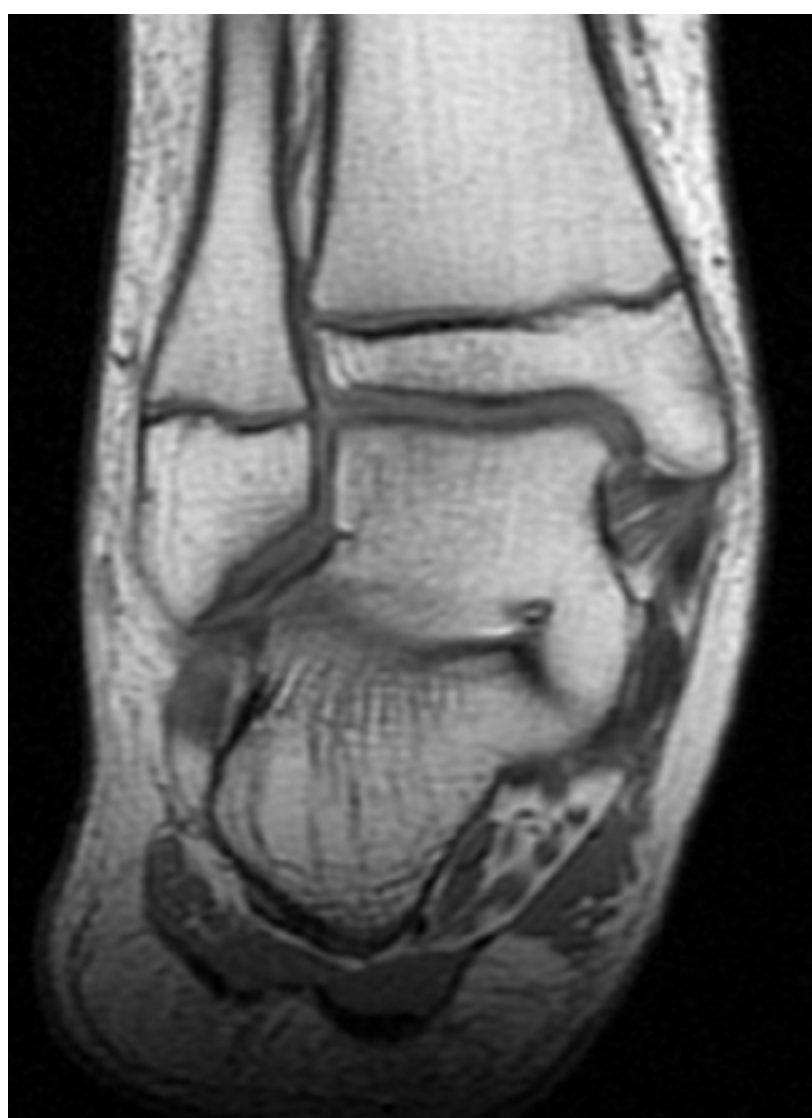

Şekil 13. Manyetik rezonans görüntüleme, çok nadiren tarsal koalisyon amacıyla kullanılabilir.

\section{Tiplendirme}

Pes planus, kabaca esnek ve sert tiplere ${ }^{[6,7]}$; bunlar da kendi içlerinde, konjenital ve kazanılmış denilen iki alt başlığa ayrılır. Pes planus tipleri Tablo 1'de görülmektedir.

\section{ESNEK PES PLANUS}

A) Konjenital

- İdiyopatik

- Aksesuvar naviküler kemik

- Serebral palsi

- Hiperpronasyon

- Marfan sendromu

- Frajil X sendromu

B) Kazanılmış

- Tibialis posterior tendon yetmezliği

- Spring bağ lezyonu

- Romatoid artrit

- Plantar fasya rüptürü

- Obezite

\section{SERT VEYA SPASTIK PES PLANUS}

A) Konjenital

- Aksesuvar naviküler kemik

- Konjenital vertikal talus

- Tarsal koalisyon

- Serebral palsi

B) Kazanılmış

- Osteokondral kırık

- Tibialis posterior tendon yetmezliği

- Reaktif peroneal spazm

- Inflamatuvar artrit

- Charcot ayağı

- Tümörler (osteoid osteoma) 


\section{IDIYOPATIK ESNEK PES PLANOVALGUS}

Pes planusun en sık görülen tipidir. Çocukluk döneminde fizyolojik bir durumdur ve genelde bilateraldir. Aile öyküsü pozitiftir. Herediter geçiş ve bağ laksitesi suçlanmıştır. Ancak, kesi nedeni bilinmemektedir. Yük altında çöken mediyal longitudinal ark, yük ortadan kalktığında normal görünür. Ayak önü abduksiyonda, topuk valgusta olabilir. Parmak ucu yürümede ark oluşur, ayrıca Jack testi pozitiftir. Topuk valgusu da parmak ucu yürümeyle düzelir. Genelde asemptomatiktir, nadiren mediyal arkta ağrı olabilir. Subtalar eklem hareketi genelde normaldir.

Esnekliğin aşırı olduğu olgularda, Brighton kriterlerine bakılmalı ve Beighton skorlaması yapılmalıdır. (Tablo 1 ve 2).

Tablo 1. Beighton skorlaması

\begin{tabular}{ll}
\hline Başparmağın kola değdirilmesi & 1 puan \\
Parmakların aşııı hiperekstansiyonu (her parmak için) & 1 puan \\
Dirseklerde aşırı hiperekstansiyon & 1 puan \\
Dizlerde rekurvasyon & 1 puan \\
Dizleri bükmeden ellerin tamamını yere değirme & 1 puan \\
\hline $5 / 9$, hipermobilitedir. &
\end{tabular}

Tablo 2. Brighton kriterleri

Major kriterler

1. Beighton skoru $>4$ puan.

2. Dört veya daha fazla eklemde üç aydan uzun süren ağrı olması.

Minör kriterler

1. Beighton skoru 1, 2, 3.

2. Üç aydan fazla süren 1-3 eklemde ağrı veya bel ağrısı veya spondilozis/spondiloliztezis.

3. Birden fazla eklemde subluksasyon veya çıkık.

4. Üç veya daha fazla yumuşak doku lezyonu (epikondilit, bursit, tenosinovit vb.).

5. Marfanoid dış görünüm.

6. Ince cilt, hiperekstansibilite, anormal skarlar.

7. Göz bulguları: düşük göz kapakları, miyop.

8. Variköz venler, fitık, uterus veya rektal prolapsus

9. Mitral valf prolapsusu.

Tanı gereklilikleri

1. İki majör kriter.

2. Bir majör, iki minör kriter.

3. Dört minör kriter.

4. İki minör kriter ve birinci derece aile öyküsü.

\section{Konservatif Tedavi}

Çocuklarda mediyal longitudinal ark 10-11 yaşına kadar gelişir. Bu yüzden, 10 yaş altı ve asemptomatik esnek pes planusta ileri tetkiklere (grafi vs) ihtiyaç yoktur; egzersiz dışı tedaviler gereksizdir ve çocuklarda psikolojik sorunların oluşmasına neden olabilir. ${ }^{[8]}$ Burada, aileden çok ebeveynlerin ikna ve tedavi edilmesi gerekir. Olguların \%20-25'inde Aşil kontraktürü vardır ve Aşil germe egzersizleri (parmak ucu yürüme, kumda yürüme, bale tarzı dans etme vb.) önerilir. Çok nadiren, mediyal ark destekli tabanlıklar ve özel ayakkabılar önerilebilir. Eğer çocuk semptomatik ise, tarsal koalisyon veya aksesuvar naviküler kemik mutlaka araştırılmalıdır.

\section{Cerrahi Tedavi}

İdiyopatik pes planovalgusta, çok nadiren de olsa cerrahi tedavi gerekebilir. Cerrahi tedavide amaç kozmetik değil, dirençli ve tedaviye yanıt vermeyen ağrıyı geçirmeye yöneliktir (Şekil 14). Aşil kısalığının giderilmesi, ayak arkasının restorasyonu ve ayak önünün aşırı abduksiyonunun düzeltilmesi hedeflenir. Yumuşak doku ve kemik ameliyatları uygulanabilir (Şekil 15). Yumuşak doku ameliyatları:

- Aşil tendon uzatması.

- Tibialis posterior plikasyonu.

- Tibialis posterior tendonunun daha distale taşınması.

- FDL transferi.

- Peroneal tendonların uzatılması.

- Talo-naviküler kapsülorafi.

\section{Ekstraartiküler subtalar vida artroerezis ameliyatı}

Subtalar ekleme vida, silikon implant, greft veya polietilen yerleştirilmesidir. Yedi yüz otuz iki hastalı bir seride \%93,7 oranında başarılı sonuç bildirilmiştir. ${ }^{[9]}$ Yirmi beş hastada komplikasyon (hemartroz, 4. metatars kırı̆̆ı, peroneal spazm) bildirilmiş ve vidalar ortalama 3,1 yılda çıkarılmıştır.

2013 yılında, AOFAS üyeleri arasında yöntem konusunda bir anket çalışması yapılmıştır. ${ }^{[10]}$ Beş yüz yetmiş iki hekimin katıldığı bu sorgulamada, özellikle Amerika'dan katılan hekimler arasında, ameliyatı eskisi kadar yapmadıkları görülmüştür. Bunların \%85'i, ağrı nedeniyle vidayı çıkarmak zorunda kaldıklarını bildirmişler; bu işlemi niye bıraktıkları sorgulandığında ise, yöntemin başarı şansı oranının düşüklüguünü neden olarak göstermişlerdir. Bizim bu konuda herhangi bir uygulamamız olmamıştır.

Esnek pes planovalgusta uygulanan kemik ameliyatları

- Mediyal küneiform fleksiyon ostetomisi.

- Lateral kolon uzatma ameliyatı (Şekil 16).

- Posterior kalkaneal kaydırma osteotomisi.

- Transvers kalkaneal osteotomisi. 


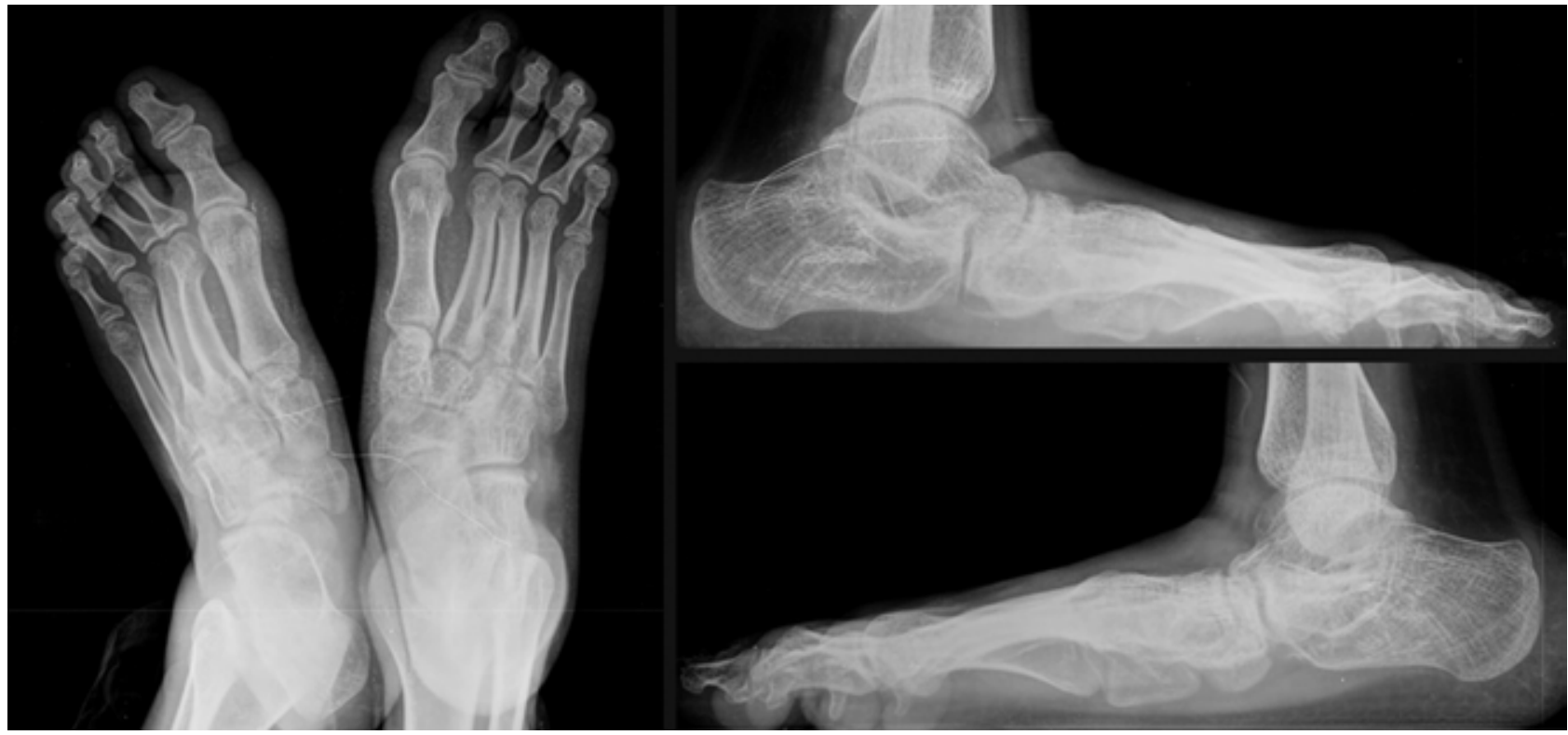

Şekil 14. Pes planovalgusu ileri düzeyde olan bir hastanın radyolojik görüntüleri.

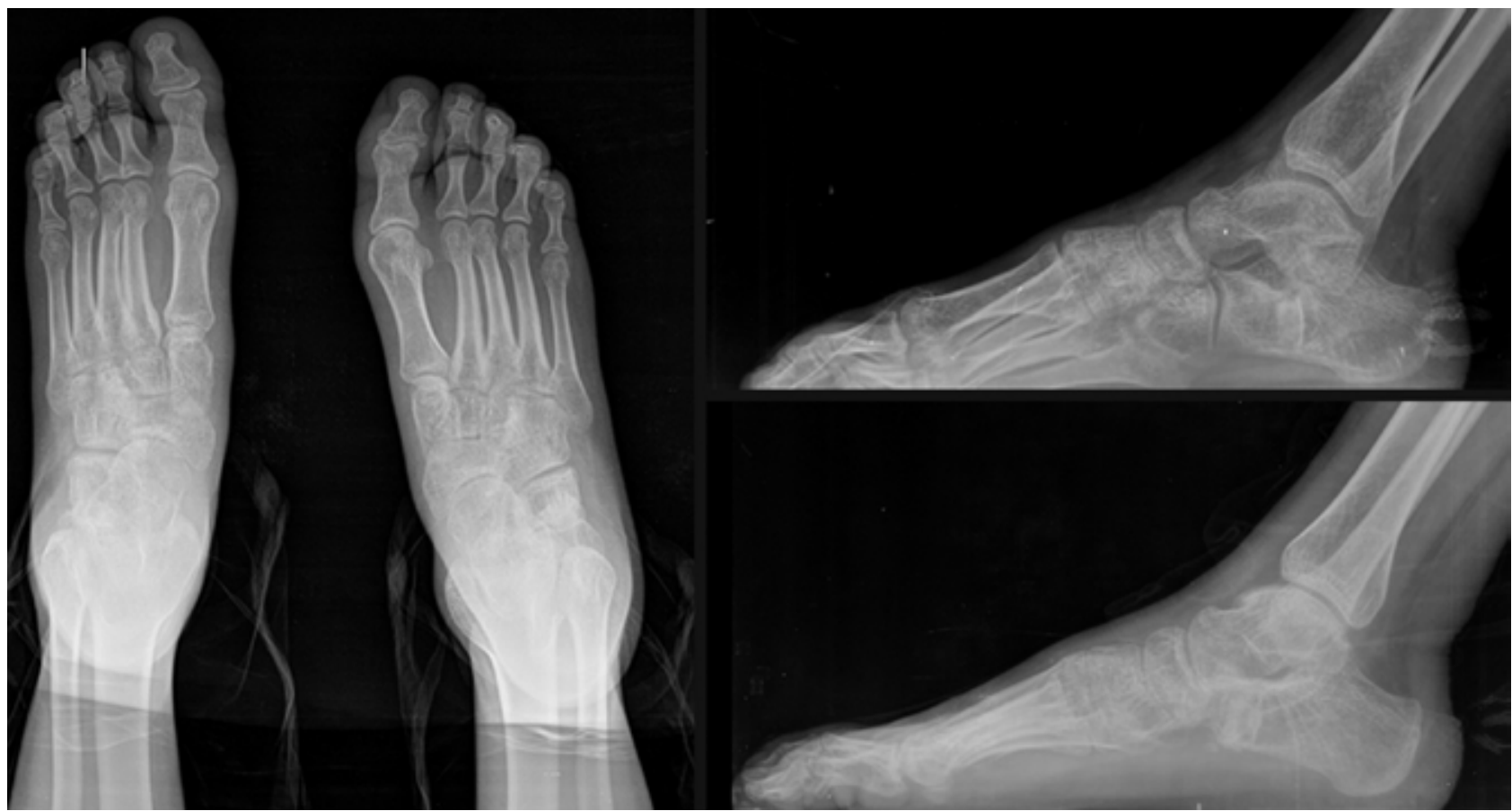

Şekil 15. Bilateral Aşiloplasti ve kalkaneal uzatma ameliyatı sonrası radyolojik görünümler.

\section{Artrodez ameliyatları}

Ayrıca artrodez ameliyatları nadiren gerekli olabilir:

- Ekstra artiküler subtalar artrodez (Dennyson Fulford, Green Grice) (Şekil 17).

- Navikula-mediyal küneiform izole artrodezi.

- Mediyal kolon artrodezi.

- Triple artrodez (Şekil 18).

\section{AKSESUVAR NAVIKÜLER KEMIK}

Prehalluks, aksesuvar sesamoid, os navikulara sekonderium, os tibiale eksternum olarak da adlandırılır. 1605 yılında Bauhin tarafından tanımlanmıştır. 1929 yılında Kidner, posterior tibial tendonun navikulaya yapışma yerinde aksesuvar kemiğe bağlı yetmezlik olduğunu ve bu yüzden mediyal arkın çökmesiyle pes 


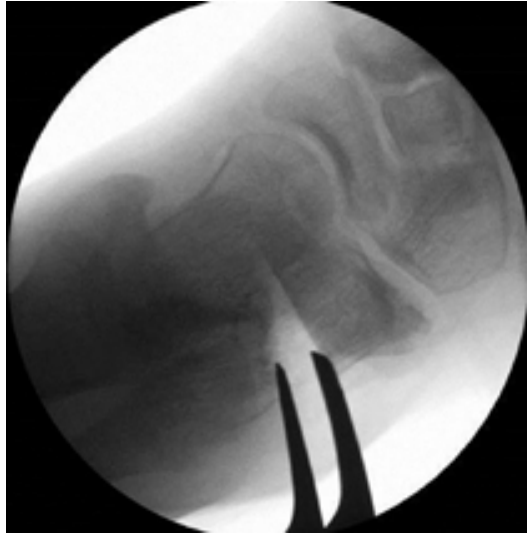

Şekil 16. Lateral kolon uzatma ameliyatı.

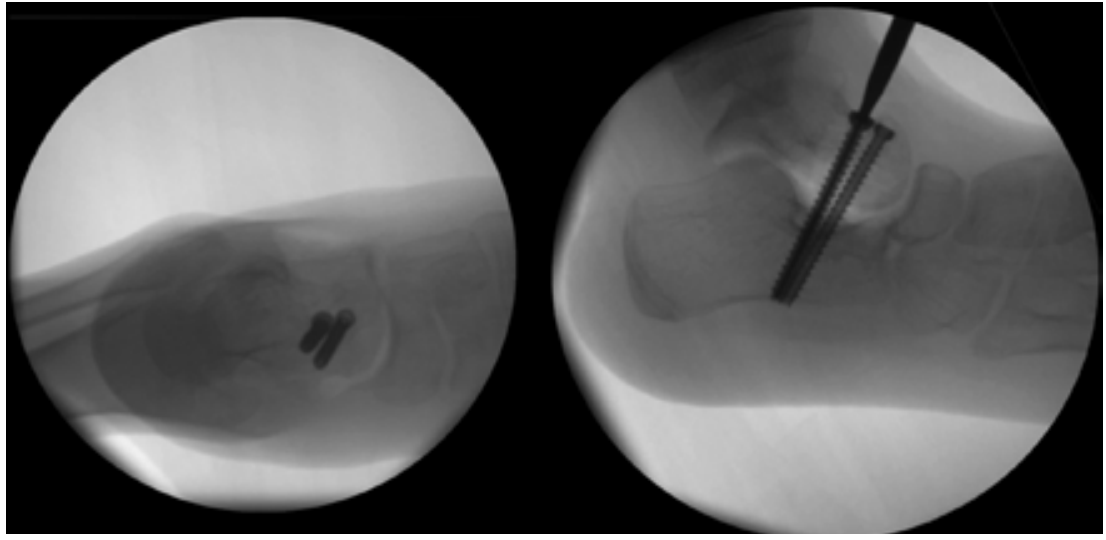

Şekil 17. Subtalar ekstrartiküler artrodez ameliyatının radyolojik görünümü.

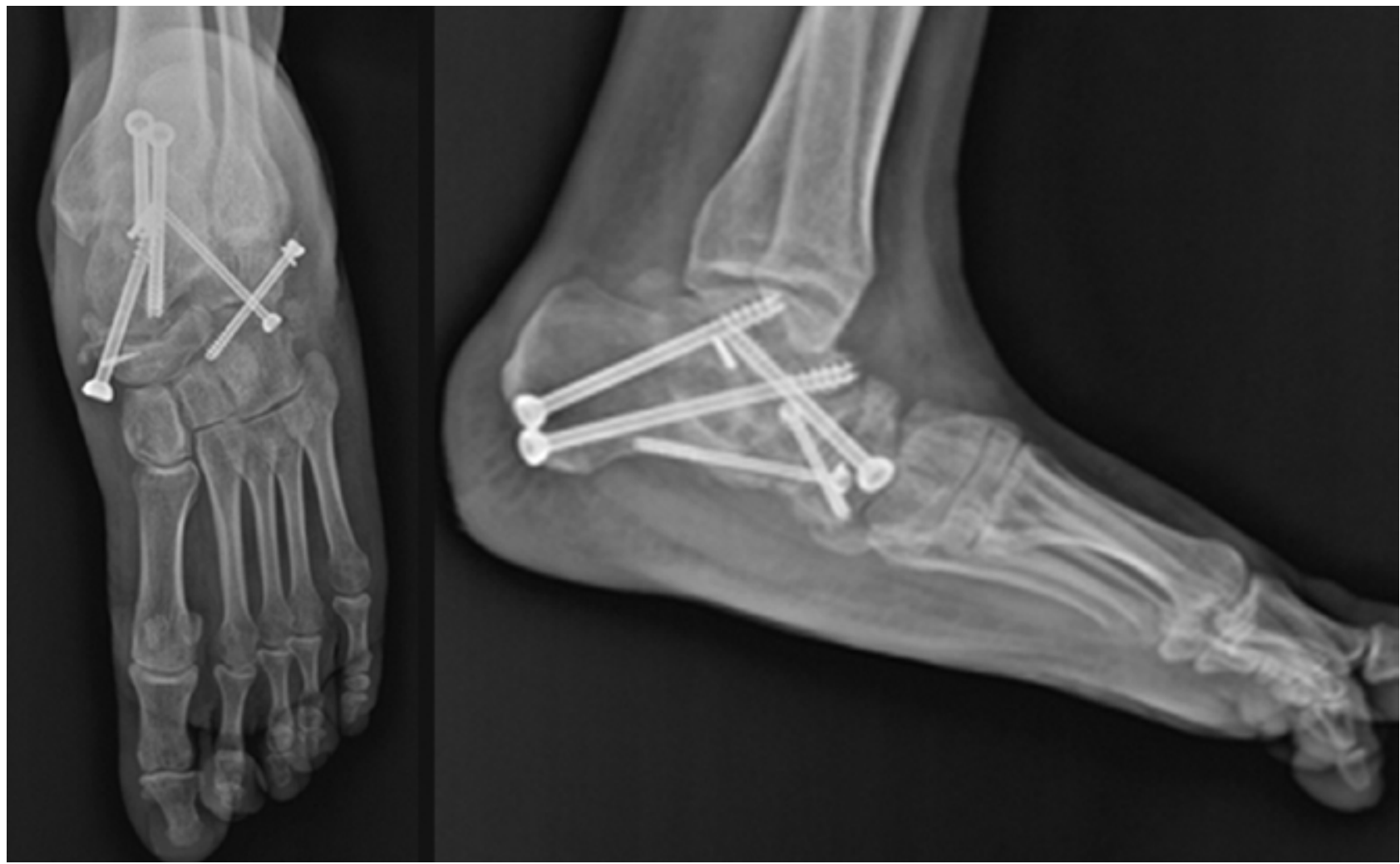

Şekil 18. Triple artrodez ameliyatının radyolojik görünümü.

planus olduğunu bildirmiştir. Pes planus nedeni olarak bildirilse de kanıtlar çok net değildir. Adolesan döneminde kemiğin belirginleşmesiyle birlikte, hekime başvurma nedeni olarak daha çok karşımıza çıkmaktadır ve genelde asemptomatiktir. Normal ayaklarda da \%10-14 oranında karşımıza çıkmaktadır.

Aksesuvar naviküler kemik üç şekilde görülür:

Tip I: Aksesuvar kemik, posterior tibial tendon içinde sesamoid halde yer alır.
Tip II: Aksesuvar kemik, naviküler gövdeye sinkondroz ile bağlı haldedir.

Tip III: Aksesuvar kemik, naviküler gövdeyle bütünleşmiştir (kemik köprü). Adeta naviküler boynuz vardır.

Genelde klinik olarak çok ciddi sorun oluşturmaz. Ancak, bazı hastalarda ciddi ağrı ve düztabanlığa neden olabilir. Konservatif tedavi girişimleri ile genelde tatminkâr sonuçlar elde edilebilir. Ayakkabı içine ped 


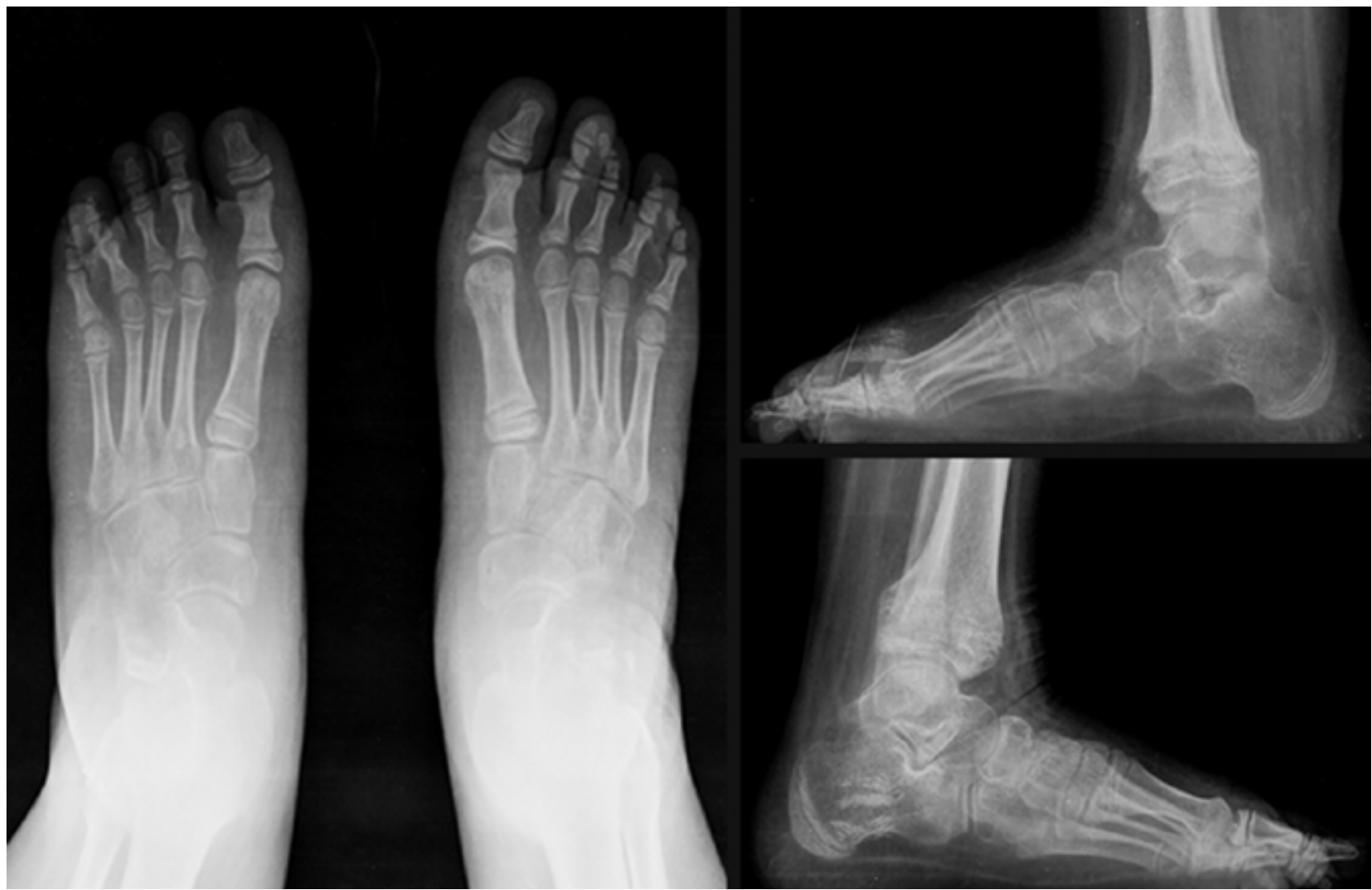

Şekil 19. İki taraflı Green-Grice, posterior tibial tendon plikasyonu ve FDC transferi.

veya tabanlık uygulamaları ve ayakkabı değişimleri ağrıyı giderir. Nadiren, kemik çıkıntı üzerine steroid enjeksiyonu uygulanabilir.

Konservatif tedaviye dirençli ağrısı olan ve ayakta oluşan ağrılı pes planus durumlarında, nadiren cerrahi tedavi uygulanabilir.

\section{Cerrahi Tedavi Seçenekleri}

1. Eksizyon.

2. Drilleme.

3. Kidner prosedürü: Aksesuvar navikula eksizyonu sonrası, tibialis posterior tendonu navikulanın daha plantar ve lateraline transfer edilir (Şekil 19).

\section{TARSAL KOALISYON}

Sert pes planus nedenidir; \%0,4-6 oranında görülmektedir ve olguların yarısı iki taraflıdır. Bir veya birden fazla tarsal kemiğin birleşerek tek bir blok haline gelmesi durumudur. Etiyolojisi tartışmalıdır. Otozomal dominant geçiş bildirilse de kanıtlanmamıştır. En sık talo-kalkaneal ve kalkaneo-naviküler tipleri görülmektedir.
Asemptomatik olabildiği gibi, ciddi ağrılı ya da hareket kısıtlılığı tablosu ile de karşımıza gelebilir. Fibröz haldeyken olguların tümü asemptomatiktir. Zaman içinde, fibröz halden sindesmotik ve sinkondrotik hale gelir ve en son ossifiye olur. Semptomların olduğu dönem, sindesmotik ve sinkondrotik olduğu dönemdir. Osseöz birleşme gerçekleştikten sonra hastada travma sonrası ağrının olması, kemik köprünün kırıldığının göstergesidir.

Fizik muayenede; Jack testi (Hubscher manevrası) genelde negatiftir. Mediyal longitudinal ark zorlama ile oluşturulamaz. Talo-kalkaneal tipte, özellikle sinus tarside ağrı vardır ve eklem hareketleri kısıtlıdır. Spastik peroneal tendonlar vardır. Bu hastaların ayak bileği burkulmalarının sık olduğu, aileleri tarafından bildirilir. Topuk genelde valgustadır ve bu deformite parmak ucu yürüyüşüyle düzelmez.

Talo-naviküler koalisyon: 3-5 yaş,

Kalkaneo-naviküler koalisyon: 8-12 yaş,

Talo-kalkaneal koalisyon: 12-16 yaşları arasında klinik bulgu vermeye başlar. 


\section{Sınıflandırma}

Etiyoloji, anatomi, doku tipi, eklem tutulumu ve yaş aralığı gibi başlıklar altında pek çok sınıflaması vardır.

Yaşa bağlı sınıflama

1. Juvenil (osseöz immatür)

a. Tip I: Ekstra-artiküler koalisyon

i. Sekonder artrit yok

ii. Sekonder artrit var

b. Tip II: İntra-artiküler koalisyon

i. Sekonder artrit yok

ii. Sekonder artrit var

2. Erişkin (Osseöz Matür)

a. Tip I: Ekstra-artiküler koalisyon

i. Sekonder artrit yok

ii. Sekonder artrit var

b. Tip II: Intra-artiküler koalisyon

i. Sekonder artrit yok

ii. Sekonder artrit var

Yerleşim yerine göre sınıflama

1. Ekstra-artiküler koalisyon

a. Kalkaneo-naviküler

b. Kübonaviküler

2. İntra-artiküler koalisyon

a. Talo-kalkaneal

i. Orta

ii. Posterior

iii. Anterior

iv. Kombinasyon

b. Talo-naviküler

c. Kalkaneo-küboid

d. Naviküloküneiform

\section{Tanı}

Genelde, basarak ön-arka ve yan grafiler kullanılır. Ancak, oblik grafiler tanıda daha yardımcıdır. Özellikle talo-kalkaneal bar oblik grafide çok net görülür. Harris aksiyel grafisinde de bar net bir şekilde görülebilir. Kalkaneo-naviküler koalisyonu olan hastalarda yan grafide, kalkaneusun ön ucu karıncayiyenin burnuna benzetildiği için "anteater nose" bulgusu denilmektedir.

Talo-kalkaneal tarsal koalisyonda ayak bileği yan grafisindeki radyolojik bulgular

- C işareti

- Halo işareti

- Gagalaşmış anterior talar proçes

- Azalmış subtalar eklem mesafesi

- Yassılaşmış ve düzleşmiş lateral proçes.

\section{Tedavi}

Ağrısız, sorun yaratmayan, asemptomatik olgularda tedavi gereksizdir. Ayakkabı modifikasyonları ve yumuşak silikon tabanlıklar kullanılabilir.

Bar eksizyonu ve yumuşak doku interpozisyonu cerrahi seçeneklerden biridir. Ciddi hareket kısıtlılığı ve ağrısı olan, ancak ayak bileği eklemlerinde artroz olmayan olgularda yapılabilir.

Şikâyetlerin fazla olduğu, pes planovalgusun yürümeyi zorlaştırdığı ve artrozun eşlik ettiği olgularda "triple artrodez" diğer bir tedavi seçeneğidir.

\section{TiBiALIS POSTERIOR TENDON YETMEZLiĞi}

Hem sert hem de esnek tip pes planus nedenidir. Yazının başında, tibialis posterior tendonunun ayağın en güçlü invertörü ve mediyal longitudinal arkı destekleyen askı yapılarından biri olduğunu söylemiştik. Eğer bu tendonda bir yetmezlik olursa, ark çöker ve pes planus veya ilerleyen dönemlerde pes planovalgus deformitesi ortaya çıkar. Genelde tek taraflıdır.

Tibialis posterior tendon yetmezliği sonucu; lateralde kalkaneo-fibular sıkışma olur ve eklem kapsülleri gerilmeye, spring bağ uzamaya ve deforme olmaya başlar. Ardından Aşil tendonu kontrakte olur. ilerleyen olgularda, deltoid bağ hasarı veya yetersizliği gelişir; subtalar ve en sonunda pantalar artroz oluşur. ${ }^{[11]}$

\section{Tibialis Posterior Tendon Yetmezliğinin Evrelemesi}

iki farklı evreleme sistemi vardır.

\section{Johnson ve Strom evrelemesi}

Evre 1: Bu başlangıç evresinde, izole tendinopati vardır ancak tendonda uzama ya da ayakta deformite yoktur.

Evre 2: Tendonda uzama ve ayakta esnek pes planus deformitesi vardır.

Evre 3: Son evrede ise tendonda uzama ve sert pes planus deformitesi vardır.

\section{Truro evrelemesi}

Evre 1: İzole tendinopati vardır. Ancak, tendonda uzama ya da ayakta deformite yoktur.

Evre 2a: Tam düzelebilen esnek pes planus mevcuttur. Ayak önü varusu $<15^{\circ}$ 'dir.

Evre 2b: Tam düzelebilen esnek pes planus vardır. Ayak önü varusu $>15^{\circ}$ 'dir.

Evre 2c: Esnek pes planus vardır. Ancak ayak arkası pasif düzelebilirken ayak önü düzelmez.

Evre 3: Sert pes planus ve sinus tarsi ağrısı vardır. Subtalar artrit gelişmiştir.

Evre 4: Sert pes planus ve ilerleyici talar tilt ile birlikte bozulmuş ayak bileği mortisi vardır. 


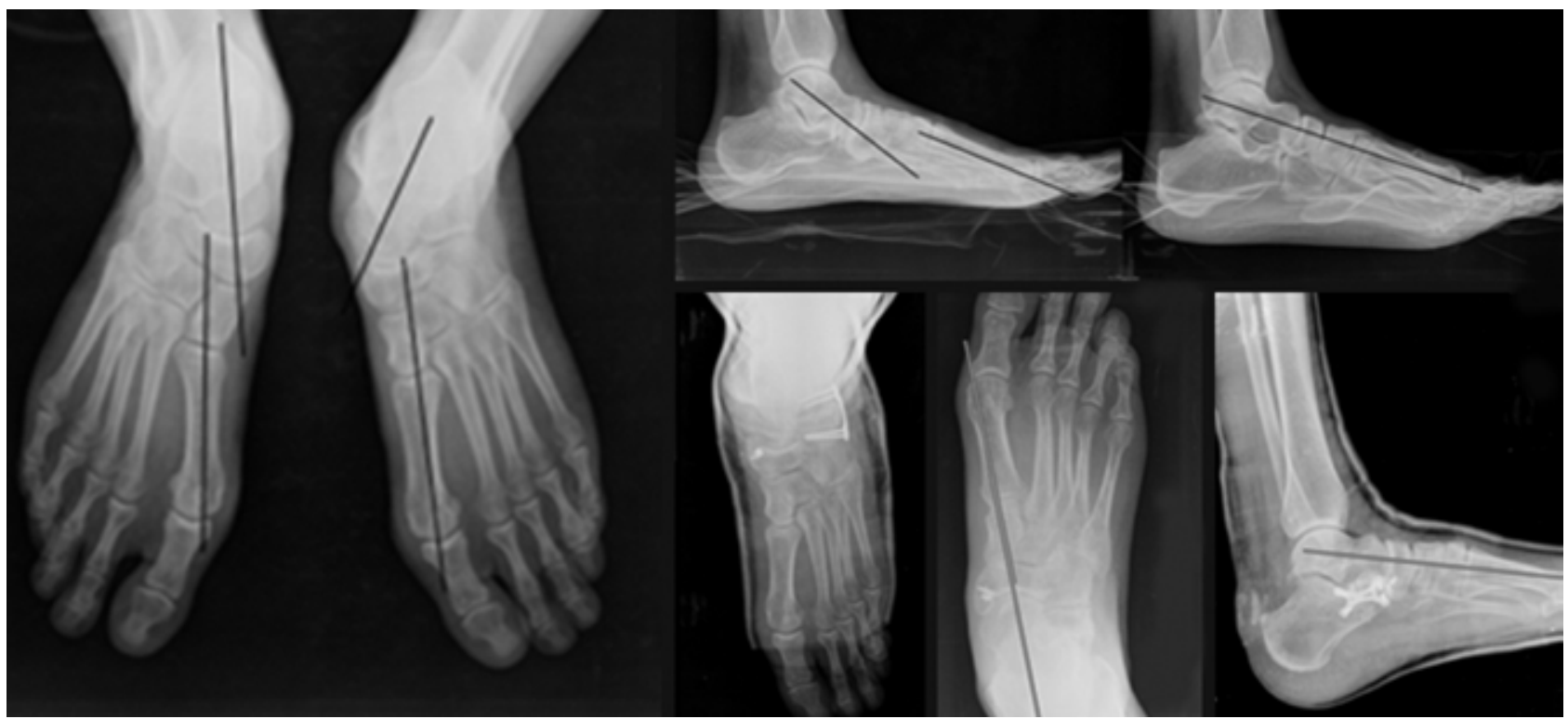

Şekil 20. Sol tibialis posterior tendon yetmezliği olan hastanın ameliyat öncesi, kalkaneal uzatma, FDC transferi ve PTT plikasyonu sonrası radyolojik görünümleri.

\section{Tedavi}

Tibialis posterior tendon yetmezliği tedavisi Truro evrelemesine göre anlatılacaktır.

\section{Evre 1}

Konservatif tedavi yeterlidir. Hastalara kilo vermesi öğütlenir. Alçı, özel ark takviyeleri veya breysler kullanılabilir, ayakkabı modifikasyonları yapılabilir. Aktivite modifikasyonları yapılır ve Aşil germe egzersizleri verilir. Ayrıca, darbelerden korunması belirtilir. Çok nadiren, ağrılı tenosinovitin çıkarılması ve bu esnada var olan parsiyel tendon rüptürünün tamiri cerrahi olarak yapılabilir.

\section{Evre 2}

Konservatif tedavi yöntemleri uygulanabilir, ancak çok yararlı olmaz. Tenosinovektomi, Aşil tendon uzatması, kalkaneusun mediyal kaydırma osteotomisi, kalkaneal uzatma osteotomisi, FDL transferi ve tibialis posterior tendonunun kısaltılarak anteriora taşınması, spring bağ tamiri, deltoid bağ rekonstrüksiyonu ve 1. tarsometatarsal (TMT) eklem artrodezi gibi cerrahi tedaviler tek tek veya kombinasyonlar şeklinde uygulanabilir (Şekil 20).

\section{Evre 3 ve 4}

Subtalar veya triple artrodez, deltoid bağ rekonstrüksiyonu veya pantalar artodez uygulanabilir.

Tibialis posterior tendon yetmezliği ameliyatları, karmaşık ve zor ameliyatlardır. Ameliyat öncesi iyi planlama yapılmalı ve yumuşak doku prosedürleri kemik işlemleri ile kombine edilmelidir. Yoksa, istenilen sonuçların elde edilmesi zordur ve nüks sık görülür.

\section{KAYNAKLAR}

1. Ricco Al, Richards S, Herring JA. Disorders of the foot. In: Herring JA, ed. Tachdjian's Pediatric Orthopaedics. 5th ed. Philadelphia, PA: Elsevier Saunders; 2014: Chapter 23. p.775-85, 827-33.

2. Huang CK, Kitaoka HB, An KN, Chao EY. Biomechanical evaluation of longitudinal arch stability. Foot Ankle 1993 14(6):353-7.

3. Kitaoka HB, Luo ZP and An KN. Analysis of longitudinal arch supports in stabilizing the arch of the foot. Clin Orthop Relat Res 1997;(341):250-6.

4. Jack EA. Naviculo-cuneiform fusion in the treatment of flat foot. J Bone Joint Surg Br 1953 35-B(1):75-82.

5. Mosca VS. Flexible Flatfoot and Skewfoot. In: Drennan JC, editor. The Child's Foot and Ankle. New York: Raven Press; 1992.

6. Staheli LT. Evaluation of planovalgus foot deformities with special reference to the natural history. J Am Podiatr Med Assoc 1987;77(1):2-6. Crossref

7. Staheli LT, Chew DE and Corbett M. The longitudinal arch. A survey of eight hundred and eighty-two feet in normal children and adults. J Bone Joint Surg Am 1987;69(3):426-8.

8. Mereday C, Dolan CM and Lusskin R. Evaluation of the University of California Biomechanics Laboratory shoe insert in "flexible" pes planus. Clin Orthop Relat Res 1972;82:45-58.

9. De Pellegrin M, Moharamzadeh D, Strobl WM, Biedermann R, Tschauner C, Wirth T. Subtalar extra-articular screw arthroereisis (SESA) for the treatment of flexible flatfoot in children. J Child Orthop 2014;8(6):479-87. Crossref

10. Murphy GA. Disorders ofTendons and Fascia and Adoslescent and Adult Pes Planus, Chapter 82. In: Canale ST, Beaty JH, Campbell WC, editors. Campbell's Operative Orthopaedics, 12. ed. Philadelphia: Elsevier, Mosby; 2013. p.3907-72.

11. Shah NS, Needleman RL, Bokhari O, Buzas D. 2013 Subtalar arthroereisis survey: the current practice patterns of members of the AOFAS. Foot Ankle Spec 2015;8(3):180-5. Crossref 